\title{
POSTHARVEST QUALITY IMPROVEMENT OF SORGHUM (Sorghum bicolor (L.) Moench) GRAINS
}

\author{
OKKY SETYAWATI DHARMAPUTRA ${ }^{1,2^{*}}$, SANTI AMBARWATI ${ }^{1}$, \\ and INA RETNOWATI ${ }^{1}$ \\ ${ }^{1}$ SEAMEO BIOTROP, Jl. Raya Tajur Km. 6, Bogor, 16134, Indonesia \\ ${ }^{2}$ Department of Biology, Faculty of Mathematics and Natural Sciences, Bogor Agricultural University, \\ Dramaga Campus, Bogor 16680, Indonesia
}

Received 29 June 2012/Accepted 26 October 2012

\begin{abstract}
The objectives of this study were (a) to investigate the effect of postharvest handling (threshing and storing) methods on the quality of sorghum (Sorghum bicolor (L) Moench) grains variety Numbu, in terms of the percentages of damaged grains and seed germination, population growth of Sitophilus zeamais, Fusarium proliferatum and F. verticillioides; fumonisin $\mathrm{B}_{1}$ and carbohydrate contents, and the percentage of weight loss during storage. The change of moisture contents of sorghum grains was also recorded. Threshing was conducted using wooden stick and a paddy thresher. Sorghum grains were packed in hermetic plastic bags. The conditions inside of the bags were airtight and normal. Each bag with different conditions inside was infested with 10 pairs of $S$. zeamais (1-14 days old). Sorghum was stored for one, two and three months under warehouse conditions. The results showed, that the moisture contents of sorghum were lower than its standard safe moisture content $(<14 \%)$ during storage. At the beginning of storage, the percentage of damaged grains caused by threshing using wooden stick was higher than that of using a paddy thresher. The increase of percentage of damaged grains was caused among others by increase $S$. zeamais population under normal oxygen concentration inside of the bag (about 21\%), consequently the percentage of weight loss was also increased. The percentage of seed germination of sorghum threshed using wooden stick was lower than that of threshed using a paddy thresher. The percentage of seed germination decreased with the increase of storage duration. Population of F. proliferatum and F. verticillioides decreased with the increase of storage duration. Fumonisin $\mathrm{B}_{1}$ content of sorghum threshed using wooden stick was higher than that of using a paddy thresher during one, two and three months of storage. Fumonisin $\mathrm{B}_{1}$ contents were considered low. In general, carbohydrate content of sorghum threshed using either wooden stick or paddy thresher from the beginning up to three months of storage were not significantly different. Threshing using a paddy thresher was better in comparison to threshing using wooden stick.
\end{abstract}

Key words: postharvest quality, sorghum, Sorghum bicolor

\footnotetext{
$\overline{\text { *Corresponding author : okky@biotrop.org }}$
} 


\section{INTRODUCTION}

As foodstuff, sorghum (Sorghum bicolor (L) Moench) is the fifth most important cereal after rice, wheat, maize, and barley in the world. Sorghum can adapt to broad agroecology, gives high production, and is more resistant to drought, pests and diseases, compared to other food crop. It has also high nutritional content which is consequently good to be used either as alternative food or feedstuff.

According to Suarni (2001) sorghum has carbohydrate content of $80.42 \%$ as compared to $86.45 \%$ in milled rice and $79.95 \%$ in maize. In terms of protein, sorghum has slightly higher content $(10.11 \%)$ than milled rice $(9.28 \%)$, but slightly lower than maize $(11.02 \%)$. Sorghum's lipid content value $(3.65 \%)$ is between milled rice $(1.88 \%)$ and maize $(5.42 \%)$. The use of sorghum as foodstuff in the form of flour is more beneficial, because it is easier to be processed into food products such as cake, cookies, bread and noodle. The capability of sorghum flour substitution upon wheat flour varied, i.e. for cookies, cake, bread and noodle was $50-75 \%, 30-50 \%$, $20-25 \%$ and $15-20 \%$, respectively (Suarni 2004). Sorghum grains could substitute maize for feed stuff, because the nutritional content of sorghum is not so different from that of maize, (Sirappa 2003).

Since long time ago sorghum plant has been recognized by farmers in Indonesia, especially in Java, West Nusa Tenggara and East Nusa Tenggara. Nevertheless, the production of sorghum is still low. Although in Indonesia the production of sorghum is still low compared to other countries such as India, China and United States, it is equally important to pay attention to the postharvest handling of this commodity to maintain its good quality during storage.

Cultivation and development of sorghum are important to anticipate food crisis caused by global warming. In Indonesia, the low production of sorghum grain is due to (a) the nonavailability of appropriate technology for sorghum handling and processing after harvest, (b) the limited knowledge on how to process sorghum grain into various food products, (c) the lower price of sorghum grains compared to milled rice, maize and peanuts.

The postharvest handling (drying, threshing and storing) can affect the quality of sorghum. Dharmaputra et al. (2010) reported that based on the surveys conducted in Demak and Wonogiri Regencies in 2010, the postharvest handling of sorghum practiced by farmers and collectors was not carried out appropriately, therefore sorghum grains were easily attacked by insects. The dominant insect species found were Sitophilus zeamais and Tribolium castaneum. The most common fungi found in sorghum were Aspergillusflavus, Fusarium semitectum and F. verticillioides.

During storage, sorghum could be infested by insects, microorganisms, mites and rats. Insects are considered the most significant cause of postharvest losses. Among microorganisms, fungi are the most important cause of deterioration of stored grains. The role of insects in fungal infection cannot be disregarded. Aside from injuring grains, insects also serve as carriers of fungi. Furthermore, the metabolic activities of insects produce heat and moisture (especially during longterm storage) which stimulate fungal growth. Fungal infection in grains can cause discoloration, decrease 
in germination, physical quality and nutritional contents, and also mycotoxin contamination (Sauer et al. 1992).

Fumonisins are important mycotoxins, produced mainly by F. proliferatum and F. verticillioides in several agricultural products worldwide, especially in maize and sorghum (Marasas et al. 1988; Abdel-Hafez et al. 1990; da Silva et al. 2000). The former name of F. verticillioides is F. moniliforme. According to Desjardins (2006) there are four kinds of fumonisins occurring at significant levels in naturally contaminated grain, i.e. fumonisin $\mathrm{B}_{1}, \mathrm{~B}_{2}, \mathrm{~B}_{3}$ and $\mathrm{B}_{4}$. The most toxic among these four kinds of fumonisins is fumonisin $B_{1}$ which can cause leukoencephalomalacia in equines (Marasas et al. 1988) and rabbits, pulmonary edema in swine (Bucci et al. 1996; Harrison et al. 1990) and it has been reported as a probable cause of esophageal cancer in humans (Marasas 2001). A high incidence of esophageal cancer has been observed in certain geographic areas and ethnic groups in Africa, Asia and Latin America.

In Indonesia, no research has been done on fumonisin level in sorghum. The method of postharvest handling is one of the factors that can affect the quality of sorghum. However, the postharvest practices in Indonesia are still inadequate, it is important to conduct research on the effects of different postharvest treatments on the quality of sorghum grain. This study is a continuation of the research conducted last year.

The objectives of the research were: (1) to investigate the effects of postharvest handling (threshing and storing) on the quality of sorghum grains, in terms of the percentages of damaged grains and seed germination, population growth of $S$. zeamais, F. proliferatum and F. verticillioides, fumonisin $\mathrm{B}_{1}$ and carbohydrate contents, and the percentage of weight loss; (2) to record the change of moisture contents of sorghum grains during storage, and (3) to recommend proper postharvest handling methods to ensure the quality of sorghum grains during storage.

The research results should provide recommendations to farmers, collectors, food and feed industries on the most adequate postharvest handling practices (threshing and storing) for sorghum to maintain good quality of grain during storage.

\section{MATERIALS AND METHODS}

\section{Variety of Sorghum}

The variety of sorghum used in this study was Numbu, cultivated by PT Tri Fondasi Indonesia in Balaraja Subdistrict, Tangerang Regency, West Java. The Numbu grains were harvested 95 days after sowing.

\section{Methods of Harvesting, Drying, Threshing and Winnowing}

Sorghum was harvested by cutting the panicle from the standing stalk using a sickle. Sorghum in the form of panicles was sun-dried on tarpaulin. Drying was conducted up to moisture content of about $13 \%$. Threshing was done using wooden stick and a paddy thresher. After threshing, grains were separated from dirt and chaff by winnowing. Sun-drying, threshing and winnowing were conducted in the location 
where sorghum was cultivated. Sorghum grains were then transported to SEAMEO BIOTROP, Bogor, by a car equipped with air conditioning.

\section{Methods of Packaging and Storing}

Prior to packaging, sorghum grains were:

(a) fumigated with phosphine for five days at 2 grams/ton of sorghum to control insect pest that may exist,

(b) checked for the percentage of damaged grains. Damaged grains included cracked and broken grains caused by threshing.

The grains were packed using hermetic bags under airtight conditions, i.e. oxygen concentration inside was about 18\%, and under normal conditions (oxygen concentration inside was about $21 \%$ ).

Each bag type of packaging material contained $2 \mathrm{~kg}$ of sorghum grains. Characteristics of plastic packaging material used to pack sorghum grains are presented in Table 1. In three replicates, inside of each bag type with different oxygen concentrations were treated as follows:

(a) infestation with ten pairs of adult (1-14 days old) Sitophilus zeamais,

(b) different method of threshing, and

(c) different storage duration.

The bags designated as "control" were not infested with S. zeamais, but were also subjected to different methods of threshing as well as storage durations. Sorghum grains were stored for one, two and three months under warehouse conditions. Bags containing sorghum were placed on wooden shelves randomly. The temperature and relative humidity of the storage were recorded using a thermohygrograph.

\section{Sampling Methods}

Grain samples were collected from each bag before storage and subsequently every month thereafter until three months of storage. In samples infested with $S$. zeamais, the insects were separated from the sorghum grains using a sieve, they were then preserved in vials containing $70 \%$ ethanol. After that, each sample was divided three times using a box sample divider to obtain working samples for the determination of moisture content, percentages of damaged grains and seed germinations, population of F. proliferatum and F. verticillioides; fumonisin $\mathrm{B}_{1}$ and carbohydrate contents, and a reserve sample.

\section{Determination of Quality Parameters}

The following quality parameters were determined in the experiments: Moisture Content, Percentages of Damaged Grains, Seed Germinations, Populations of S. zeamais, F. proliferatum and F. verticillioides, Fumonisin $\mathrm{B}_{1}$ and carbohydrate contents, Percentage of Weight Loss. 
Postharvest quality improvement of sorghum-Okky S. Dharmaputra et al.

Table 1. Laboratory analyses of plastic packaging material*

\begin{tabular}{llllll}
\hline $\begin{array}{c}\text { Parameter } \\
\text { test }\end{array}$ & $\begin{array}{c}\text { Condition } \\
\text { of sample }\end{array}$ & Unit & $\begin{array}{c}\text { Test } \\
\text { method }\end{array}$ & $\begin{array}{c}\text { Test } \\
\text { result }\end{array}$ & $\begin{array}{c}\text { Uncertainty at } \mathbf{9 5 \%} \\
\text { confidence level, } \\
\mathbf{k = 2}\end{array}$ \\
\hline $\begin{array}{l}\text { WVTR (Water } \\
\text { Vapour }\end{array}$ & Good & $\begin{array}{l}\mathrm{g} / \mathrm{m}^{2} / \\
\text { day }\end{array}$ & $\begin{array}{l}\text { ASTMF } \\
1249-\end{array}$ & 2.8946 & \pm 0.3619 \\
Transmission & & & & \\
Rate) & & & & \\
Temperature & & & & \\
$=37.8{ }^{\circ} \mathrm{C}$ \\
RH $=100 \%$
\end{tabular}

Moisture content of sorghum (based on wet basis) was determined as soon as samples were collected using DELMHORST Model G-7 Moisture Meter. This instrument has been caliberated and cross-checked using oven method. Two replicates were used for each sample.

Damaged grains were collected after one, two and three months of storage including cracked, broken and damaged grains (damage caused by $S$. zeamais or fungi). The number of grains used for the determination of damaged grain percentage was 300 per sample.

Percentage of seed germination was determined based on blotter method (Mathur and Kongsdal 2001). Population growth of $S$. zeamais was determined based on the number of adult insects per $\mathrm{kg}$ of each sample. Fusarium verticillioides and F. proliferatum were isolated and enumerated using a serial dilution method followed by pour plate method on Dichlorane Chloramphenicol Peptone Agar (DCPA) (Pitt \& Hocking 2009). Fumonisin $B_{1}$ and carbohydrate contents were determined using Liquid Chromatography-Mass Spectrophotometry (LC-MS) (Zöllner \& Mayer-Helm 2006) and SNI (1992) methods, respectively.

The percentage of weight loss was determined at the end of storage. Grain samples contained in each bag were weighed before and at the end of storage. Grain samples were taken periodically from each bag and weighed.

\section{Statistical Analyses}

The data were analyzed using Completely Randomized Factorial Design with four factors. The first, second, third and fourth factors were the method of threshing, oxygen concentrations inside of the bags, presence or absence of $S$. zeamais, and storage duration, respectively. 
BIOTROPIA Vol. 19 No. 2, 2012

\section{RESULTS AND DISCUSSIONS}

\section{Moisture Content}

Moisture content of grains is one of the important factors that affected the deterioration of grains during storage. High moisture content will give an opportunity for fungal growth. SNI (1992) defines 14\% as the maximum moisture content of sorghum grains during storage.

Method of threshing, duration of storage and their interaction gave very significant differences in moisture content of sorghum grain. Moisture content of sorghum threshed using wooden stick at the beginning of storage, subsequently after 1,2 and 3 months of storage was significantly different from samples threshed using a paddy thresher during the same periods.

The lowest moisture content $(13.30 \%)$ was found in sorghum grain threshed using wooden stick before storage and after two months of storage (Table 2). The highest moisture content $(13.72 \%)$ was found in sorghum grain threshed using wooden stick after three months of storage. It was significantly different from that threshed using wooden stick before storage or after two months of storage.

According to Christensen et al. (1992) moisture content is always in equilibrium with the relative humidity of storage room. Bala (1997) reported, that moisture content is also affected by the temperature of storage room. In this study, the range and mean of the temperature of storage room during storage were $26.8-29.3^{\circ} \mathrm{C}$ $\left(28.1^{\circ} \mathrm{C}\right)$, while the range and mean of relative humidity of storage room were 47.5 $70.8 \%(64.5 \%)$ (Table 3$)$.

Lacey and Magan (1991) reported that among the microorganisms which colonize grains, fungi are the most tolerant to low relative humidity, consequently fungi has an important role in the deterioration of grain.

\section{Percentage of Damaged Grains}

Method of threshing, duration of storage and their interaction gave very significant differences (at 99\% significance level) in the percentage of damaged grain, while the interaction among method of threshing, infested with insects, oxygen concentration and duration of storage affected less significantly ( $95 \%$ significance level) the percentage of damaged grain.

At the beginning of storage, the percentage of damaged grain of sorghum threshed using a wooden stick was higher and significantly different from that threshed with a paddy thresher. The percentage of damaged grain in each treatment combination increased and was significantly different during three months of storage. The sorghum grains threshed either using wooden stick or a paddy thresher, not infested with insects, packed under low or normal oxygen concentrations did not gave any significant difference on the percentage of damaged grains after three months of storage (Table 4).

The lowest percentage of damaged grain was found in sorghum threshed using a paddy thresher, not introduced with insect and stored under low oxygen concentration $(\mathrm{MSOH})$ at the beginning of storage $(5.00 \%)$, while the highest was found in sorghum 
Postharvest quality improvement of sorghum-Okky S. Dharmaputra et al.

Table 2. Moisture content of sorghum grains threshed using wooden stick and a paddy thresher during storage

\begin{tabular}{ccc}
\hline \multirow{2}{*}{$\begin{array}{c}\text { Duration of storage } \\
\text { (month) }\end{array}$} & \multicolumn{2}{c}{ Moisture content (\%) } \\
\cline { 2 - 3 } & Mooden stick & Paddy thresher \\
\cline { 2 - 3 } & Mean \pm STD & Mean \pm STD \\
\hline 0 & $13.30 \pm 0.08 \mathrm{a}$ & $13.38 \pm 0.05 \mathrm{~b}$ \\
2 & $13.55 \pm 0.05 \mathrm{c}$ & $13.67 \pm 0.15 \mathrm{de}$ \\
3 & $13.30 \pm 0.09 \mathrm{a}$ & $13.52 \pm 0.12 \mathrm{c}$ \\
& $13.72 \pm 0.07 \mathrm{e}$ & $13.64 \pm 0.09 \mathrm{~d}$ \\
\hline
\end{tabular}

Note: Numbers followed by the same letter do not differ significantly according to Duncan's Multiple Range Test at $95 \%$ confidence level

Table 3. Range and mean values of temperature and relative humidity during storage

\begin{tabular}{ccc}
\hline $\begin{array}{c}\text { Duration of storage } \\
\text { (month) }\end{array}$ & $\begin{array}{c}\text { Range and mean of } \\
\text { temperature } \\
(\mathbf{O} \mathbf{C})\end{array}$ & $\begin{array}{c}\text { Range and mean of } \\
\text { relative humidity } \\
\mathbf{( \% )}\end{array}$ \\
\hline $0-1$ & $27.4-29.3(28.3)$ & $54.0-70.8(59.8)$ \\
$1-2$ & $26.8-28.9(28.3)$ & $47.5-68.6(57.7)$ \\
$2-3$ & $27.2-28.2(27.8)$ & $48.7-58.6(57.9)$ \\
\hline
\end{tabular}

Table 4. Percentage of damaged grains of sorghum caused by various treatments

\begin{tabular}{ccccc}
\hline Treatment & \multicolumn{4}{c}{ Duration of storage (months) } \\
\cline { 2 - 5 } & $\mathbf{0}$ & $\mathbf{1}$ & $\mathbf{2}$ & $\mathbf{3}$ \\
\hline KS0H & $9.90 \pm 0.00 \mathrm{fegd}$ & $10.63 \pm 2.63 \mathrm{fcegd}$ & $12.08 \pm 2.23 \mathrm{cebd}$ & $20.20 \pm 0.08 \mathrm{a}$ \\
$\mathrm{KS} 0 \mathrm{~N}$ & $8.44 \pm 1.66 \mathrm{fhgi}$ & $11.62 \pm 0.16 \mathrm{fcebd}$ & $14.60 \pm 0.00 \mathrm{~b}$ & $18.48 \pm 2.53 \mathrm{a}$ \\
$\mathrm{KS} 1 \mathrm{H}$ & $7.66 \pm 1.26 \mathrm{hjgi}$ & $12.53 \pm 2.80 \mathrm{cbd}$ & $13.33 \pm 1.54 \mathrm{cb}$ & $19.73 \pm 1.62 \mathrm{a}$ \\
$\mathrm{KS} 1 \mathrm{~N}$ & $9.38 \pm 0.35 \mathrm{fhegd}$ & $10.03 \pm 3.03 \mathrm{fegd}$ & $11.99 \pm 2.95 \mathrm{cebd}$ & $21.47 \pm 0.83 \mathrm{a}$ \\
$\mathrm{MS} 0 \mathrm{H}$ & $5.00 \pm 0.22 \mathrm{j}$ & $8.98 \pm 0.22 \mathrm{fhegi}$ & $9.76 \pm 0.19$ fegd & $10.45 \pm 0.00$ fcegd \\
MS0N & $5.04 \pm 0.36 \mathrm{j}$ & $5.92 \pm 0.12 \mathrm{ji}$ & $7.79 \pm 0.82 \mathrm{hjgi}$ & $9.45 \pm 0.45$ fhegd \\
MS1H & $6.20 \pm 0.45 \mathrm{hji}$ & $9.01 \pm 0.00 \mathrm{fhegi}$ & $8.93 \pm 2.06$ fhegi & $10.05 \pm 0.05$ fegd \\
MS1N & $5.07 \pm 0.47 \mathrm{j}$ & $7.74 \pm 4.46$ hjgi & $8.91 \pm 1.63$ fhegi & $9.87 \pm 0.56$ fegd
\end{tabular}

Note: Numbers followed by the same letter do not differ significantly according to Duncan's Multiple Range Test at $95 \%$ confidence level

$\mathrm{K}=$ wooden stick $; \quad \mathrm{S} 0=$ not infested with $S$. reamais; $\quad \mathrm{N}=$ normal oxygen concentration $( \pm 21 \%)$

$\mathrm{M}=$ a paddy thresher $; \quad \mathrm{S} 1=$ infested with $S$. zeamais; $\quad \mathrm{H}=$ low oxygen concentration $( \pm 18 \%)$

threshed using wooden stick, infested with insect and stored under normal oxygen concentration (KS1N) after three months of storage (21.47\%) (Table 4).

According to Dobie et al. (1991) S. zeamais is an important insect pest in stored grain. In Indonesia $S$. zeamais could be a dominant insect species in milled rice and maize. The adult can live for several months up to one year. Their eggs, larvae and 
pupae are found inside of grain. Dharmaputra et al. (2010) reported, that the dominant insect species of sorghum stored at farmer and collector levels in Wonogiri and Demak Regencies were $S$. zeamais and T. castaneum.

The existence of damaged grain before storage was due to the different threshers. During storage, the increase of damaged grain in sorghum infested with insects could be caused by insect and fungal attacks, while that not infested with insects may be due to fungal infection.

\section{Percentage of Seed Germination}

Effects of threshing and storage duration was highly different in the percentage of seed germination. Percentage of seed germination in sorghum threshed using wooden stick $(91.04 \%)$ was lower and significantly different from that of sorghum threshed using a paddy thresher $(93.33 \%$ ) (Table 5). It was stronger correlated with the percentage of damaged grain in sorghum threshed using wooden stick than in grain threshed with a paddy thresher. Percentage of seed germination during storage decreased with the increase storage duration (Table 6). Percentage of seed germination at the beginning of storage $(93.88 \%)$ was significantly different from that after one $(91.96 \%)$, two $(91.88 \%)$ and three months of storage $(91.04 \%)$. Percentage of seed germination after one, two and three months of storage was not significantly different. According to Neergard (1979) fungal infection in the embryo of seed is a factor causing the decrease of seed germination during storage. Percentage of seed germination after three months of storage was more than $90 \%$, thus the percentage is still higher than the minimum standard germination of seed, i.e. $70 \%$ (Directorate General of Food Crops 1984).

The capability of seed to germinate is affected by the atmosphere composition of storage room, but its effect is lower compared to the moisture content and the temperature of the storage (Priestley 1986).

Table 5. Percentage of seed germination in sorghum threshed with wooden stick vs a paddy thresher

\begin{tabular}{cc}
\hline Thresher & Seed germination (\%) \\
\hline A wooden stick & $91.04 \mathrm{a}$ \\
Paddy thresher & $93.33 \mathrm{~b}$ \\
\hline
\end{tabular}

Note: Numbers followed by the same letter do not differ significantly according to Duncan's Multiple Range Test at $95 \%$ confidence level

Table 6. Percentage of seed germination in sorghum grains during storage

\begin{tabular}{cc}
\hline Duration of storage (month) & $\begin{array}{c}\text { Seed germination (\%) } \\
\text { Mean } \pm \text { STD }\end{array}$ \\
\hline 0 & $93.88 \pm 4.07 \mathrm{a}$ \\
1 & $91.96 \pm 2.20 \mathrm{~b}$ \\
2 & $91.88 \pm 2.47 \mathrm{~b}$ \\
3 & $91.04 \pm 3.22 \mathrm{~b}$ \\
\hline Note: Numbers followed by the same letter do not differ significantly according to Duncan's Multiple Range
\end{tabular}
Test at $95 \%$ confidence level 


\section{Population of $F$. proliferatum and $F$. verticillioides}

Population of F. proliferatum

The duration of storage gave very significant difference ( $99 \%$ significance level) to the population of F. proliferatum, while the interaction between the infestation by insects and the duration of storage, and the interaction among the four factors (method of threshing, presence of $S$. zeamais, oxygen concentration and duration of storage) gave significant difference ( $95 \%$ significance level) to the population of $F$. proliferatum.

Population of F. proliferatum in sorghum subjected to different postharvest treatments differed in the samples examined immediately after harvest but no clear trend could be detected. In contrast, no significant difference could be detected between treatments after 1,2 and 3 months in storage (Table 7). The population of F. proliferatum in sorghum subjected to various treatments and storage duration fluctuated considerably resulted to very high standard deviation. The fluctuation was probably due to the existence of other fungal species which were antagonistic or synergistic to the growth of F. proliferatum. The population of F. prolliferatum in grain subjected to various treatments decreased with the increase of storage duration.

Population of $\mathrm{F}$. verticillioides

The duration of storage gave significant difference in F. verticillioides population. Population of $F$. verticillioides decreased significantly with the increase of storage duration (Table 8). The population of F. verticillioides at the beginning of storage $(1370 \mathrm{cfu} / \mathrm{g})$ was significantly higher than that after three months of storage (433 $\mathrm{cfu} / \mathrm{g})$. The decrease of F. verticillioides population was probably due to the existence of other fungal species which were antagonistic to the growth of F. verticillioides.

According to Neergaard (1979) there are two groups of fungi infecting grains, i.e. field fungi and postharvest fungi. Fusarium belongs to field fungi, while Aspergillus, Eurotium and Penicillium belong to postharvest fungi. During storage, the activity of field fungi often stops, because they need high relative humidity $(\geq 90 \%)$.

Table 7. Population of Fusarium proliferatum (cfu/g) in sorghum grains related to various treatments

\begin{tabular}{lcccc}
\hline \multirow{2}{*}{ Treatment } & \multicolumn{4}{c}{ Duration of storage (month) } \\
\cline { 2 - 5 } & $\mathbf{0}$ & $\mathbf{1}$ & $\mathbf{2}$ & $\mathbf{3}$ \\
\hline $\mathrm{KS} 0 \mathrm{H}$ & $7333.33 \pm 10540.44 \mathrm{ba}$ & $433.33 \pm 133.50 \mathrm{c}$ & $289.00 \pm 329.02 \mathrm{c}$ & $311.00 \pm 371.55 \mathrm{c}$ \\
$\mathrm{KS} 0 \mathrm{~N}$ & $1855.67 \pm 650.07 \mathrm{c}$ & $933.33 \pm 851.25 \mathrm{c}$ & $133.33 \pm 88.44 \mathrm{c}$ & $77.67 \pm 134.52 \mathrm{c}$ \\
$\mathrm{KS} 1 \mathrm{H}$ & $755.67 \pm 680.58 \mathrm{c}$ & $578.00 \pm 943.70 \mathrm{c}$ & $1444.67 \pm 1924.89 \mathrm{c}$ & $333.33 \pm 296.52 \mathrm{c}$ \\
$\mathrm{KS} 1 \mathrm{~N}$ & $2677.67 \pm 2117.54 \mathrm{bc}$ & $377.67 \pm 77.36 \mathrm{c}$ & $533.33 \pm 695.72 \mathrm{c}$ & $300.00 \pm 185.71 \mathrm{c}$ \\
MS0H & $1700.00 \pm 1010.79 \mathrm{c}$ & $411.00 \pm 416.61 \mathrm{c}$ & $500.00 \pm 433.35 \mathrm{c}$ & $266.33 \pm 57.74 \mathrm{c}$ \\
MS0N & $9155.67 \pm 8592.37 \mathrm{a}$ & $167.00 \pm 0.00 \mathrm{c}$ & $113.00 \pm 72.11 \mathrm{c}$ & $255.33 \pm 385.09 \mathrm{c}$ \\
MS1H & $1516.50 \pm 118.09 \mathrm{c}$ & $1167.00 \pm 707.11 \mathrm{c}$ & $2033.50 \pm 2781.05 \mathrm{c}$ & $233.50 \pm 47.38 \mathrm{c}$ \\
MS1N & $1333.25 \pm 585.33 \mathrm{c}$ & $358.50 \pm 421.22 \mathrm{c}$ & $933.25 \pm 968.68 \mathrm{c}$ & $1025.00 \pm 1540.18 \mathrm{c}$ \\
\hline
\end{tabular}

Note: Numbers followed by the same letter do not differ significantly according to Duncan's Multiple Range Test at $95 \%$ confidence level 


\section{Fumonisin $\mathbf{B}_{1}$ Content}

Method of threshing and duration of storage, and their interaction gave very significant differences in fumonisin $\mathrm{B}_{1}$ content. Fumonisin $\mathrm{B}_{1}$ content in sorghum threshed using wooden stick was higher and significantly different from that of sorghum threshed with a paddy thresher after one, two and three months of storage (Table 9). Fumonisin $B_{1}$ content in sorghum threshed using wooden stick fluctuated and showed significant differences at various points in time during storage. The content in sorghum threshed with a paddy thresher also fluctuated, but showed no significant differences between sampling times. The fluctuation of fumonisin $\mathrm{B}_{1}$ content in sorghum was probably due to the existence of certain strains of $F$. verticillioides which can produce fumonisin $\mathrm{B}_{1}$.

The lowest fumonisin $\mathrm{B}_{1}(1.58 \mathrm{ppb})$ was found in sorghum threshed using wooden stick at the beginning of storage, while the highest in sorghum also threshed using wooden stick after one month of storage (27.55 ppb).

FAO (2004) reported the maximum allowable fumonisin $\mathrm{B}_{1}$ content in some countries. In France the maximum fumonisin $\mathrm{B}_{1}$ content allowed in cereals and their processed products is $1000 \mathrm{ppb}$, in Cuba for maize and milled rice $1000 \mathrm{ppb}$, in Switzerland for maize $1000 \mathrm{ppb}$.

The existence of F. moniliforme and other toxigenic species of Fusarium, and fumonisin production in the field and their products are determined by environmental factors in the field, during transportation and storage (Gamanya \& Sibanda 2001).

\section{Carbohydrate Content}

The duration of storage and the interaction between method of threshing were very significant $(99 \%$ significance level). The carbohydrate content in sorghum before storage $(67.33 \%)$ was not significantly different from that after two (68.64\%) and three months $(67.02 \%)$ of storage, but it was significantly different from that after one month of storage $(70.81 \%)$ (Table 10$)$.

The carbohydrate content in sorghum threshed using wooden stick and a paddy thresher after one and two months of storage was significantly different, while the content at the beginning of storage and after three months of storage was not significantly different. The lowest carbohydrate content was found in sorghum threshed using a paddy thresher at the beginning of storage (65.98\%), while the highest content was found in sorghum threshed using a paddy thresher after one month of storage $(74.11 \%)$.

Table 8. Population of Fusarium verticillioides during storage

\begin{tabular}{cc}
\hline $\begin{array}{c}\text { Duration of storage } \\
\text { (month) }\end{array}$ & $\begin{array}{c}\text { Population of } F \text {. verticillioides (cfu/g) } \\
\text { Mean } \pm \text { STD }\end{array}$ \\
\hline 0 & $1370.88 \pm 1320.68 \mathrm{a}$ \\
1 & $1293.04 \pm 2202.69 \mathrm{ba}$ \\
3 & $1157.38 \pm 1491.77 \mathrm{ba}$ \\
$433.00 \pm 590.17 \mathrm{~b}$ \\
\hline
\end{tabular}

Numbers followed by the same letter do not differ significantly according to Duncan's Multiple Range Test at $95 \%$ confidence level 
Postharvest quality improvement of sorghum-Okky S. Dharmaputra et al.

Table 9. Fumonisin $\mathrm{B}_{1}$ content (ppb) in sorghum grains threshed using wooden stick and a paddy thresher during storage

\begin{tabular}{ccc}
\hline $\begin{array}{c}\text { Duration of storage } \\
\text { (month) }\end{array}$ & Wooden stick & Paddy thresher \\
\cline { 2 - 3 } & Mean \pm STD & Mean \pm STD \\
\hline 0 & $1.58 \pm 0.81 \mathrm{a}$ & $1.94 \pm 1.47 \mathrm{a}$ \\
2 & $27.55 \pm 12.87 \mathrm{~d}$ & $3.22 \pm 2.71 \mathrm{a}$ \\
3 & $20.43 \pm 7.56 \mathrm{c}$ & $4.65 \pm 4.66 \mathrm{a}$ \\
1 & $12.57 \pm 12.25 \mathrm{~b}$ & $2.43 \pm 3.32 \mathrm{a}$ \\
\hline
\end{tabular}

Numbers followed by the same letter do not differ significantly according to Duncan's Multiple Range Test at $95 \%$ confidence level

Suarni (2001) reported that carbohydrate content in sorghum was $80.42 \%$. In this study the range of carbohydrate contents in samples that had been threshed using wooden stick was 66.69 - $71.28 \%$ during storage, while the content in sorghum threshed using a paddy thresher was 65.98 - 74.11\% during storage (Table 11). The difference of carbohydrate contents in this study and that of Suarni (2001) was probably due to the difference of sorghum variety and the method of cultivation. Garraway and Evans (1984) reported, that carbon source needed for fungal growth were (among others) the carbohydrates (e. g. monosachharides). The capability of fungi to use sugars could be different among fungal species, even sometimes among different strains of the same species.

\section{Sitophilus zeamais Population}

The method of threshing and duration of storage differ very significant by $(99 \%$ significance level) in the population of adult $S$. zeamais, while the interaction between the two factors gave a significant difference (95\% significance level). Population of $S$. zeamais in sorghum threshed using wooden stick after one and three months of storage was higher and significantly different from that of samples threshed with a paddy thresher (Table 12). In general $S$. zeamais population either in sorghum threshed using wooden stick or a paddy thresher increased during storage. According to Dobie et al. (1991) the actual length of the life cycle of $S$. zeamais depends also upon the type and quality of grains being infested, i.e. in different varieties of maize, mean development periods of $S$. zeamais at $27^{\circ} \mathrm{C}$ and relative humidity $70 \%$ have shown to vary from 31 to 37 days.

\section{Percentage of Weight Loss}

The duration of storage gave very significant difference ( $99 \%$ significance level) in weight loss of sorghum. The percentage of weight loss increased and differed significantly with the increase of storage duration (Table 13). The weight losses of sorghum at the beginning of storage, subsequently after one, two and three months of storage were $1.62,1.92,2.21$ and $2.30 \%$, respectively. The increase of weight loss was due among others by the increase of the percentage of damaged grain (Table 4) and population of $S$. zeamais (Table 12) during storage. 
BIOTROPIA Vol. 19 No. 2, 2012

Table 10. Carbohydrate content in sorghum grains during storage

\begin{tabular}{cc}
\hline Duration of storage (month) & $\begin{array}{c}\text { Carbohydrate content (\%) } \\
\text { Mean } \pm \text { STD }\end{array}$ \\
\hline 0 & $67.33 \pm 3.33 \mathrm{~b}$ \\
1 & $70.81 \pm 5.57 \mathrm{a}$ \\
2 & $68.64 \pm 4.05 \mathrm{~b}$ \\
3 & $67.02 \pm 1.45 \mathrm{~b}$ \\
\hline
\end{tabular}
Test at $95 \%$ confidence level

Table 11. Carbohydrate content $(\%)$ in sorghum grains threshed using a wooden stick and a paddy thresher during storage

\begin{tabular}{ccc}
\hline $\begin{array}{c}\text { Duration of storage } \\
\text { (month) }\end{array}$ & Wooden stick & Paddy thresher \\
\cline { 2 - 3 } & Mean \pm STD & Mean \pm STD \\
\hline 0 & $68.68 \pm 4.18 \mathrm{ab}$ & $65.98 \pm 1.32 \mathrm{a}$ \\
2 & $67.51 \pm 3.57 \mathrm{a}$ & $74.11 \pm 5.34 \mathrm{c}$ \\
3 & $71.28 \pm 2.28 \mathrm{~b}$ & $66.00 \pm 3.71 \mathrm{a}$ \\
\hline
\end{tabular}

Note: Numbers followed by the same letter do not differ significantly according to Duncan's Multiple Range Test at $95 \%$ confidence level

Table 12. Population of adult Sitophilus zeamais (number $/ \mathrm{kg}$ ) in sorghum grains threshed using wooden stick and a paddy thresher during storage tests

\begin{tabular}{ccc}
\hline $\begin{array}{c}\text { Duration of storage } \\
\text { (months) }\end{array}$ & Wooden stick & Paddy thresher \\
\cline { 2 - 3 } & Mean \pm STD & Mean \pm STD \\
\hline 0 & $10.00 \pm 0.00 \mathrm{a}$ & $10.00 \pm 0.00 \mathrm{a}$ \\
2 & $20.38 \pm 3.37 \mathrm{c}$ & $13.62 \pm 1.81 \mathrm{~b}$ \\
3 & $15.98 \pm 3.73 \mathrm{~b}$ & $15.29 \pm 1.97 \mathrm{~b}$ \\
& $21.11 \pm 2.40 \mathrm{c}$ & $15.02 \pm 1.16 \mathrm{~b}$ \\
\hline
\end{tabular}

Note: Numbers followed by the same letter do not differ significantly according to Duncan's Multiple Range

Test at $95 \%$ confidence level

Table 13. Percentage of weight loss of sorghum grains during storage

\begin{tabular}{cc}
\hline Duration of storage (months) & $\begin{array}{c}\text { Weight loss (\%) } \\
\text { Mean } \pm \text { STD }\end{array}$ \\
\hline 0 & $1.62 \pm 0.44 \mathrm{a}$ \\
1 & $1.92 \pm 0.54 \mathrm{~b}$ \\
2 & $2.21 \pm 0.51 \mathrm{bc}$ \\
3 & $2.30 \pm 0.49 \mathrm{c}$ \\
\hline Note : Numbers followed by the same letter do not differ significantly according to Duncan's Multiple Range
\end{tabular}

Test at $95 \%$ confidence level 


\section{CONCLUSIONS}

1. The moisture content of sorghum grain subjected to various postharvest treatments was lower than that of safe moisture content of sorghum for storage $(<14 \%)$.

2. - At the beginning of storage the percentage of damaged grains of sorghum threshed using wooden stick was higher than that of threshed using a paddy thresher.

- The percentage of damaged grain in each treatment increased with the increase of storage duration.

- After three months of storage the highest percentage of damaged grain was found in sorghum threshed using wooden stick, infested with Sitophilus zeamais, and stored under normal oxygen concentration $( \pm 21 \%)$.

3. - The seed germination percentage of sorghum threshed using wooden stick was lower than that of samples threshed with a paddy thresher.

- During storage the percentage of seed germination decreased with the increase of storage duration.

4. Populations of Fusarium proliferatum and F. verticillioides decreased with the increase of storage duration. Fumonisin $B_{1}$ content in sorghum threshed with wooden stick was higher than that of samples threshed with a paddy thresher during one, two and three months of storage. Fumonisin $\mathrm{B}_{1}$ contents were considered low. In general carbohydrate content in sorghum threshed using either wooden stick or a paddy thresher from the beginning of storage up to three months of storage was not significantly different. After three months of storage, $S$. zeamais population either in sorghum threshed using wooden stick or a paddy thresher was higher and significantly different from that of at the beginning of storage. The percentage of weight loss of sorghum increased with the increase of storage duration. After three months of storage the percentage of weight loss was higher and and significantly different compared to that at the beginning of storage or any other sampling time before three months. The two different oxygen concentrations inside of the bags did not produce any significant difference in the quality of sorghum. Threshing using a paddy thresher was better in comparison to threshing using a wooden stick.

\section{ACKNOWLEDGMENTS}

The authors gratefully acknowledge the financial support of the Government of Indonesia. Thanks are due to PT Tri Fondasi Indonesia for providing sorghum grains, to The Agency for Chemical and Packaging, Jakarta for analyzing plastic packaging material, to PT Angler BioChemLab, Surabaya for analyzing fumonisin $\mathrm{B}_{1}$ content, to Indonesian Center for Agricultural Post Harvest Research and Development for analyzing carbohydrate content; to Mr. Edi Suryadi, Ms. Nijma Nurfadila, Ms. Lia Amelia, Ms. Dwi Ayu Kencana Ungu, for their assistance. We would like also to express our appreciation to the reviewers of this manuscript. 
BIOTROPIA Vol. 19 No. 2, 2012

\section{REFERENCES}

Abdel-Hafez SII, Moubasher H, Shoreit M, Ismail M. 1990. Fungal flora associated with combine harvester wheat and sorghum dusts from Egypt. J Basic Microbiol 30: 467-9.

Bala BK. 1997. Drying and Storage of Cereal Grains. New Hampshire: Science Publishers.

Bucci TJ, Kansen DK, Labord JB. 1996. Leukoencephalomalacia and hemorrhage in the brain of rabbits gavaged with mycotoxin fumonisin $B_{1}$. Natural Toxins 4: 51-2.

Christensen CM, Miller BS, Johnston JA. 1992. Moisture and Measurement. In: Sauer DB, editor. Storage of Cereal Grains and Their product. $4^{\text {th }}$ edition. Minnesota: American Association of Cereal Chemist. p 39 54.

da Silva JB, Pozzi CR, Mallozzi MAB, Ortega EM, Correa B. 2000. Mycoflora and occurrence of aflatoxin $B_{1}$ and Fumonisin $B_{1}$ during storage of Brazilian sorghum. J Agric Food Chem 48(9): 4352-6.

Dharmaputra OS, Ambarwati S, Retnowati I. 2010. The Occurrence of Insects and Fungi, and Aflatoxin B Contamination of Stored Sorghum in Demak and Wonogiri Regencies, Central Java. Biotropia 18 (2): 102-22.

Desjardins AE. 2006. Fusarium. Chemistry, Genetics, and Biology. St. Paul: The American Phytopathological Society.

Direktorat Jenderal Tanaman Pangan. 1984. Pedoman Sertifikasi Benih. Jakarta: Direktorat Bina Produksi Tanaman Pangan.

Dobie P, Haines CP, Hodges RJ, Prevett PF, Rees DP. 1991. Insects and Arachnids of Tropical Stored Products: Their Biology and Identification. A Training Manual. $2^{\text {nd }}$ edition. Kent: Natural Resources Institute.

FAO. 2004. Worldwide Regulations for Mycotoxins in Food and Feed in 2003. FAO Food and Nutrition Paper 81. Rome: Food and Agriculture Organization of the United Nations.

Gamanya R, Sibanda L. 2001. Survey of Fusarium moniliforme (F. verticillioides) and production of fumonisin $\mathrm{B}_{1}$ in cereal grains and oilseeds in Zimbabwe. Int J of Food Microbiol 71: 145-9.

Garraway MO, Evans RC. 1984. Fungal Nutrition and Physiology. New York: John Wiley \& Sons.

Harrison LR, Colvin BM, Greens JT, Newman LE, Cole JR. 1990. Pulmonary edema and hydrothorax in swine produced by fumonisin $\mathrm{B}_{1}$, a toxic metabolite of Fusarium verticilliodes. J Vet Diagn Invest 2: 217-21.

Lacey J, Magan N. 1991. Fungi in cereal grain; their occurrence, water and temperature relationship. In: Chelkowski J, editor. Cereal Grain: Mycotoxins, Fungi and Quality in Drying and Storage. Amsterdam: Elsevier Science. p 77-120

Marasas WFO, Kellerman TS, Gelderblom WCA, Coetzer JAW, Thiel PG, van der Lught JJ. 1988. Leukoencephalomalacia in horse induced by fumonisin $\mathrm{B}_{1}$ isolated from Fusarium verticillioides. Ondersteport J Vet Res 55: 197-203.

Marasas WFO. 2001. Discovery and occurrence of the fumonisins: a historical perspective. Environmental Health Perspective 109: 239-243

Mathur SB, Kongsdal O. 2003. 1st edition. Common Laboratory Seed Health Testing Methods for Detecting Fungi. Bassersdorf: International Seed Testing Association.

Neergaard P. 1979. Seed Pathology. Vol. I. London: The MacMillan Press Ltd.

Pitt JI, Hocking AD. 2009. Fungi and Food Spoilage. New York: Springer.

Priestley DA. 1986. Seed Aging; Implications for Seed Storage and Resistance in the Soil. Ithaca: Comstock Publ. Assoc.

Sauer DB, Meronuck RA, Christensen CM. 1992. Microflora. In: Sauer DB (editor). Storage of Cereal Grains and Their Product. $4^{\text {th }}$ ed. Minnesota: American Association of Cereal Chemist. p 313-40.

Sirappa MP. 2003. Prospek pengembangan sorgum di Indonesia sebagai komoditas alternatif untuk pangan, pakan, dan industri. J Litbang Pertanian 22 (4): 133-140. 
Postharvest quality improvement of sorghum-Okky S. Dharmaputra et al.

[SNI] Standar Nasional Indonesia. 1992. Sorgum. SNI 01- 3157 - 1992. Jakarta: Badan Standardisasi Nasional.

Suarni. 2001. Tepung Komposit Sorgum, Jagung dan Beras untuk Pembuatan Kue Basah (Cake). Risalah Penelitian Jagung dan Serealia Lain. Vol.6, p 55-60. Maros: Balai Penelitian Tanaman Jagung dan Serealia.

Suarni. 2004. Pemanfaatan tepung sorgum untuk produk olahan.J Litbang Pertanian 23 (4): 145-51.

Zöllner P, Mayer-Helm B. 2006. Trace mycotoxin analysis in complex biological and food matrices by liquid chromatography - atmospheric pressure ionization mass spectrometry. J of Chromatography A 1136: $123-69$. 